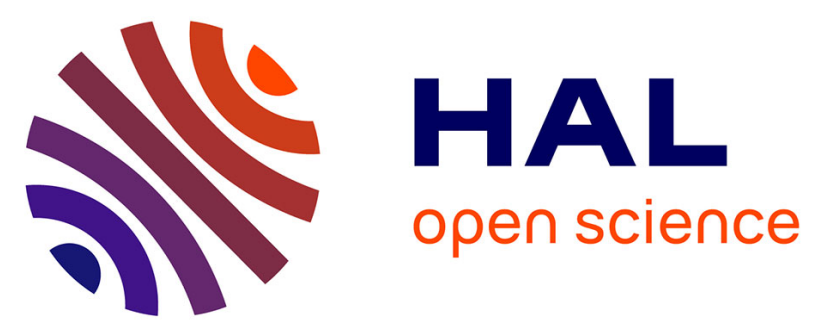

\title{
Absence of predictable long-term molecular effect of ulipristal acetate (UPA) on the endometrium
}

Kamila Kolanska, Justine Varinot, Geoffroy Canlorbe, Christine Bergeron, Arsène Mekinian, Perrine Goussault Capmas, Martin Koskas, Emile Daraï, Selim Aractingi, Sofiane Bendifallah, et al.

\section{To cite this version:}

Kamila Kolanska, Justine Varinot, Geoffroy Canlorbe, Christine Bergeron, Arsène Mekinian, et al.. Absence of predictable long-term molecular effect of ulipristal acetate (UPA) on the endometrium. 2019, 38 (5), pp.825-834. 10.1016/j.rbmo.2018.12.013 . hal-02352143

\section{HAL Id: hal-02352143 \\ https://hal.sorbonne-universite.fr/hal-02352143}

Submitted on 6 Nov 2019

HAL is a multi-disciplinary open access archive for the deposit and dissemination of scientific research documents, whether they are published or not. The documents may come from teaching and research institutions in France or abroad, or from public or private research centers.
L'archive ouverte pluridisciplinaire HAL, est destinée au dépôt et à la diffusion de documents scientifiques de niveau recherche, publiés ou non, émanant des établissements d'enseignement et de recherche français ou étrangers, des laboratoires publics ou privés. 
1 Short title: UPA and the endometrium

2 Absence of predictable long-term molecular impact of ulipristal acetate (UPA) on the

3 endometrium

4

5 Kamila Kolanska $^{\mathrm{a}, \mathrm{b}}$, Justine Varinot $^{\mathrm{c}}$, Geoffroy Canlorbe $^{\mathrm{b}, \mathrm{d}}$, Christine Bergeron ${ }^{\mathrm{e}}$, Arsène Mekinian ${ }^{\dagger}$,

6 Perrine Capmas $^{\mathrm{g}}$, Martin Koskas ${ }^{\mathrm{h}}, \mathrm{Emile} \mathrm{Daraï}^{\mathrm{a}, \mathrm{b}}$, Selim Aractingi ${ }^{\mathrm{b}, \mathrm{i}}$, Sofiane Bendifallah ${ }^{\mathrm{a}, \mathrm{b}}$, Nathalie

7 Chabbert-Buffet ${ }^{\mathrm{a}, \mathrm{b}}$

8 a Service de gynécologie obstétrique et médecine de la reproduction, Hôpital Tenon, AP-HP,

9 Sorbonne Université, 4 rue de la Chine, 75020 Paris, France

10 b INSERM UMRS 938, Faculté de médecine Pierre et Marie Curie, Site Saint-Antoine, 27 rue Chaligny,

1175571 PARIS cedex 12, France

12 c Service d'anatomopathologie, Hôpital Tenon, AP-HP, Sorbonne Université, 4 rue de la Chine, 75020

13 Paris, France

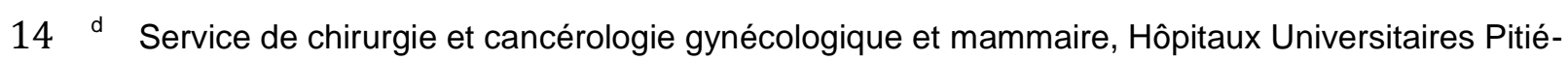

15 Salpêtrière, Charles-Foix, Sorbonne Université, 47/83, boulevard de l'Hôpital, 75013 Paris, France

16 e Cerba Laboratory, 95066 Cergy Pontoise, France

17 f Service de médecine interne, Hôpital Saint Antoine, AP-HP, 184 rue du Faubourg Saint Antoine,

1875012 Paris, Sorbonne Université, France

19 g Service de gynécologie obstétrique, CHU de Bicêtre, AP-HP, 78, rue du Général-Leclerc, 94270 Le

20 Kremlin-Bicêtre, France

$21{ }^{\mathrm{h}}$ Service de gynécologie obstétrique, CHU de Bichat, AP-HP, 75018 Paris, France

22 i Faculté de médecine Paris 5 Descartes, 12 rue de l'Ecole de Médecine, 75006 Paris, France

24 Address for correspondence:

25 Nathalie Chabbert-Buffet, MD PhD

26 Service de gynécologie obstétrique et médecine de la reproduction

27 Hôpital Tenon, AP-HP

284 rue de la Chine

2975020 Paris, France

30 Tel: +33156017748 Email: nathalie.chabbert-buffet@aphp.fr 


\section{ABSTRACT}

32 Research Question: To describe the effects of ulipristal acetate (UPA) on the expression of

33 endometrial proliferation and maturation markers.

34 Design: A total of 45 endometrium-containing blocks of hysterectomy samples from non-menopausal women with a diagnosis of moderate to severe symptoms of uterine fibroids: 14 women operated on at the end of a three-month course of UPA; 4 women who had discontinued UPA treatment 1-12 months before surgery; 27 control unexposed samples (14 in the proliferative and 13 in the secretory phase). Immunohistochemical staining of Ki67, vascular endothelial growth factor-receptor 2 (VEGFR2), estradiol receptor (ER), PR, interleukin-15 (IL-15), indoleamin-2,3-dioxygenase (IDO) and C-C motif chemokine ligand-2 (CCL2) markers were analysed in both endometrial compartments and layers.

Results: Under UPA, ER and PR expression is similar to the proliferative phase in both layers, although with a decrease in cell proliferation. IL-15, IDO and CCL2 expressions are similar to the proliferative phase suggesting a progesterone-antagonist effect of UPA. VEGFR2 staining suggests a trend to a mixed agonist-antagonist effect. No significant difference is observed in the post-UPA proliferative phase group as compared to the control group in both layers of the endometrium.

Conclusion: The effect of three-month UPA treatment is mostly progesterone receptor (PR) antagonist-like. After treatment discontinuation there are no signs of any long-term effects of this molecule on both endometrial proliferation and maturation. Therefore UPA may be administered to women willing to conceive in the short term without consequences for further implantation.

KEYWORDS: Endometrium, ulipristal acetate, basalis, functionalis, maturation

\section{ABBREVIATIONS:}

54 CCL2 - C-C motif chemokine ligand-2

55 ER - estradiol receptor

56 IDO - indoleamin-2,3-dioxygenase

$57 \quad$ IL-15 - interleukin-15

58 PAEC - progesterone receptor modulator associated endometrial changes 
60 SPRM - selective progesterone receptor modulator

61 UPA - ulipristal acetate

62 VEGFR2 - vascular endothelial growth factor-receptor 2

63

\section{ACKNOWLEDGEMENTS}

65 We thank Pr Nathalie Lédée for many productive discussions, and Anita Rodenas (Department of 66 Pathology, Tenon University Hospital) and Michèle Oster (UMRS 938) for their technical contributions.

67 We thank Felicity Kay for professional editing of the manuscript.

68 Study funding/competing interest(s): This work was in part funded by an educational grant from 69 Gedeon Richter, France. Gedeon Richter employees were not involved in the design of the project or 70 the interpretation of the results, or in any of the steps of the publication process, including writing of 71 the manuscript.

72 N.C.-B., C.B., M.K. and E.D. are board members of Gedeon Richter France SAB. All other authors 73 have no conflicts of interest to declare. 


\section{INTRODUCTION}

Recently, the use of ulipristal acetate (UPA), a selective progesterone receptor modulator (SPRM) has been approved in women of reproductive age as a treatment for symptomatic myomas before surgical intervention or as alternative to surgery, using a long-term sequential regimen (Donnez et al., 2012). Currently, the use of SPRMs is being evaluated in women who wish to conceive subsequently (Donnez and Dolmans, 2016). SPRMs act as progesterone receptor ligands able to induce agonistic or antagonistic activities according to the target cell (Bouchard et al., 2011).

During UPA treatment the hormonal profile is modified, with blunted progesterone levels, while estradiol levels remain in the early follicular phase range (Chabbert-Buffet et al., 2007). In addition 95\% of patients experience amenorrhea (Donnez et al., 2012). Therefore, the menstrual cycle phase cannot be defined stricto sensu under UPA.

Endometrial morphology during UPA treatment has been described as non-physiological secretory (Mutter et al., 2008; Williams et al., 2012) due to the combined progesterone receptor agonist antagonist activity of the molecule. The effects of UPA on morphology and gene expression in the superficial layer of the endometrium have been described in one study, consistent with UPA acting as a PR antagonist, although without any proliferative effects (Whitaker et al., 2017). However, the superficial layer undergoes a monthly shedding, regenerates from the basal layer, which acts as "the memory" of the endometrium, and finally, during the secretory phase, undergoes decidualization, a crucial step to allow embryo implantation (Gellersen et al., 2007; Perrier D'hauterive et al., 2002). Immune cells play a critical role in the regulation of cellular proliferation, tissue remodelling and angiogenesis in a direct and an indirect response to steroid hormones (Croxatto et al., 2014; Szekeres-Bartho et al., 2009). Their proliferation and activation are regulated under the action of progesterone by locally produced molecules, such as interleukin 15 (IL-15) (Okada et al., 2000; Wilkens et al., 2013), C-C motif ligand 2 (CCL2) (Szekeres-Bartho et al., 2009), and indoleamine 2,3dioxygenase (IDO) (Kudo et al., 2001; Munn et al., 1999). Progesterone stimulates the expression of IL-15 (Kitaya et al., 2000) and VEGFR2 (Lai et al., 2015) and the secretion of CCL2 (Caballero-Campo et al., 2002) in the human endometrium. In an in vitro model of endometrial culture progesterone increases IL-15 secretion (Okada et al., 2000) and decreases IDO expression (Kudo et al., 2004). The angiogenesis of endometrial tissue is also regulated by immune cells-produced angiogenic factors, 
104 such as vascular endothelial growth factor A (VEGFA) which interacts with its receptor VEGFR-2 105 (Lash et al., 2016).

106 The impact of UPA in the basal layer of the endometrium and its potential post-treatment impact is 107 currently poorly understood, and may impair the whole endometrial maturation process in post 108 treatment cycles.

109 Since previous data do not provide information on the impact the molecule has, either on the basal 110 layer or on the post-treatment endometrium, the aim of this study was to describe the possible effects 111 of UPA on proliferation and maturation markers in both layers of the endometrium, under the action of 112 UPA as well as after the end of treatment. 


\section{MATERIAL AND METHODS}

\section{Patients and samples}

115 Adequate endometrium-containing blocks of hysterectomy samples from non-menopausal women aged 40-52 years, with a diagnosis of moderate to severe symptoms of multiple uterine myoma with a combination of subserous and/or intramural and/or submucous fibroids requiring hysterectomy, were

118 retrospectively collected in three university hospital surgical gynaecology units (Department of 119 Gynaecology Obstetrics and Reproductive Medicine, Tenon Hospital; Department of Gynaecology 120 Obstetrics, Bicêtre University Hospital and Department of Gynaecology Obstetrics, Bichat University 121 Hospital). Four groups of patients were included in the study. The control groups, not exposed to 122 hormonal treatments or UPA, included samples of superficial and basal layers of endometrium 123 obtained in the proliferative (No-UPA proliferative phase group, $n=14$ ) and secretory phases (No124 UPA secretory phase group, $n=13$ ), classified on the basis of histological examination (Bouchard et 125 al., 1991; Noyes et al., 1975).The UPA group $(n=14)$ included women operated on at the end of a 126 three-month course of UPA (Esmya, Gedeon Richter, Paris, France, 5mg daily). The post-UPA 127 proliferative phase group $(n=4)$ was composed of women who had been treated with UPA for at least 128 three months, and who had discontinued treatment 1-12 months before surgery with a proliferative 129 phase histological examination classification.

130 The mean ages for the No-UPA proliferative phase, No-UPA secretory phase, UPA and post-UPA 131 groups were, respectively, $47.2 \pm 2.8$ years, $46.9 \pm 3.0$ years, $46.9 \pm 2.6$ years and $45.8 \pm 1.5$ years, $p$

$132=0.796$. BMI was $27.2 \mathrm{~kg} / \mathrm{m}^{2} \pm 5.5,26.7 \mathrm{~kg} / \mathrm{m}^{2} \pm 5.3,27.7 \mathrm{~kg} / \mathrm{m}^{2} \pm 6.8$ and $26.3 \mathrm{~kg} / \mathrm{m}^{2} \pm 2.0, p=0.995$ 133 for the No-UPA proliferative phase, No-UPA secretory phase, UPA and post-UPA groups, respectively, 134 and parity was $1.8 \pm 1.0$ versus $1.5 \pm 1.3$ versus $1.7 \pm 1.1$ versus $0.0 \pm 0.0, p=0.200$, respectively. 135 Among evaluated samples from the UPA group only two included focal progesterone receptor 136 modulator associated endometrial changes (PAEC) lesions.

137 The Institutional Review Board allowed retrospective sample analysis and approved the study. All 138 women gave written informed consent. 
141 Paraffin-embedded tissue sample sections of $10 \mu \mathrm{m}$ were processed and stained with haematoxylin

142 and eosin by standard methods. All evaluations were performed under blinded conditions by one 143 expert pathologist (CB). Endometrial differentiation was assessed by histological dating (Noyes et al., 144 1975) and evaluation of ER and PR expressions (Bouchard et al., 1991). Presence of progesterone 145 receptor modulator associated endometrial changes (PAEC) was noted.

\section{Immunohistochemistry}

148 We selected proliferation (Ki67), angiogenesis (vascular endothelial growth factor-receptor 2 149 [VEGFR2]), immune pathways (interleukin-15 [IL-15], indoleamin-2,3-dioxygenase [IDO], C-C motif chemokine ligand-2 [CCL-2]) and endocrine maturation (ER, PR) markers on the basis of their major 151 functions in human endometrial homeostasis (Ban et al., 2013; Dimitriadis et al., 2005; Jones et al., 152 1998; Kayisli et al., 2002; Kitaya et al., 2000; Lai et al., 2015; Munn et al., 1999; Sedlmayr et al., 2002).

153 Sample sections of $5 \mu \mathrm{m}$ were subjected to deparaffinisation. and antigen retrieval (Supplemental Table

154 I). All sections were subjected to quenching of endogenous peroxidase activity by incubation with $3 \%$ 155 hydrogen peroxide (GPR Rectapur VWR Chemicals, Radnor, PA, USA), and non-specific activity was 156 blocked with appropriate serum before incubation with antibodies specific to IDO, CCL2, IL-15 and 157 VEGFR2 (Table A.1). Appropriate matched IgG was applied as a negative control.

158 The primary antibodies were detected using an avidin-biotin peroxidase technique with anti-rabbit or 159 anti-mouse secondary antibodies as appropriate and Vectastain Elite ABC kit (Vector Laboratories, 160 Inc., Burlingame, CA, USA). The reaction was developed with 3,3'-diaminobenzidine (DAB; Vector 161 Laboratories, Inc.). Sections were counterstained with Mayer's haematoxylin and mounted with Immu162 Mount (Thermo Scientific Shandon, Kalamazoo, MI, USA). Positive and negative controls 163 (replacement of the primary antibody by appropriate non-immune serum) were included in each 164 staining run.

165 The immunostaining of PR, ER and Ki67 was performed using the automated method Automate 166 BenchMark XT, Roche Ventana®, (Ventana Medical Systems, Inc., Rotkreuz, Switzerland) (Table A.1). 167 The demasking was done by heating at $\mathrm{pH}$ 8.8. The slides were incubated over $24 \mathrm{~h}$ with pre-diluted 168 anti-PR and anti-ER antibodies and over 32h with anti-Ki67 antibody (dilution 1/150). Then the slides 169 were incubated with anti-rabbit and anti-mouse antibodies and revealed by UltraView Universal DAB 
170 (ref. 760-500, Ventana Medical Systems, Inc.). Representative images were captured using a Nikon

171 Eclipse 90i microscope equipped with a Nikon DSFi1 camera (Nikon Ltd, UK).

\section{Semi-quantitative analysis of immunostaining}

174 Blinded interpretation of immunostained sections was performed by an expert pathologist (JV). The 175 percentage of stained cells was evaluated at 200x magnification. The stromal cells and glandular 176 epithelium were evaluated separately in each layer of the endometrium. The percentage of 177 immunostained cells was noted. For Ki67 a score from 1-3 was used, where 1 corresponded to $<5 \%$ 178 of stained cells, 2 to $5-50 \%$ of stained cells and 3 to $>50 \%$ of stained cells.

179 To determine the protein expression profile under UPA treatment, immunostaining was compared 180 between the UPA group and the No-UPA proliferative and secretory phase groups. In order to analyse 181 the possible persistent endometrial effect of UPA, the post-UPA proliferative phase group was 182 compared to the control No-UPA proliferative phase group. In addition, the effects of UPA were

183 evaluated in both endometrial layers and in both cellular compartments, i.e. stromal cells and the 184 glandular epithelium.

185

\section{Statistical analysis}

187 The Kruskal-Wallis test was performed to compare the continuous variables concerning study group 188 characteristics. The qualitative variables were analysed using the chi-square test. The semi189 quantitative evaluation of the immunostaining for each cellular type in each layer of the endometrium 190 was expressed as a percentage and was compared using the Mann-Whitney test.

191 All reported $p$ values are two-sided and $p<0.05$ was considered statistically significant. All analyses 192 were performed using the GraphPad Prism 7. 


\section{RESULTS}

\section{UPA treatment induces epithelial ER and PR expression in both layers of the endometrium}

ER and PR are well known markers of progesterone-induced endometrial epithelium maturation. Their expression was decreased in the No-UPA secretory phase as compared to the No-UPA proliferative phase in the glandular epithelium in both layers $(65.8 \% \pm 29.4$ versus $100.0 \% \pm 0.0, p<0.0001$ and $37.1 \% \pm 38.8$ versus $100.0 \% \pm 0.0, p<0.0001$ for ER and PR, respectively in the superficial layer and $88.3 \% \pm 21.2$ versus $100.0 \% \pm 0.0, p=0.03$ and $73.3 \% \pm 22.3$ versus $100.0 \% \pm 0.0, p<0.0001$ for ER and PR, respectively in the basal layer) as previously described in women without any uterine disorder (Bouchard et al., 1991) (Figure 1). However, ER and PR staining in the No-UPA secretory phase was significantly lower in the superficial layer when it was compared with the basal layer $(65.8 \% \pm 29.4$ versus $88.3 \% \pm 21.3, p=0.04$ and $37.1 \% \pm 38.8$ versus $73.3 \% \pm 22.3, p=0.02$, respectively) (Figure A.1).

Under UPA, the ER immunostaining level was very intense in stromal and epithelial cells, in both endometrial layers (Figure 1) and the percentage of stained cells was generally increased as compared to the No-UPA secretory phase, except for the stromal compartment of the basal layer $(90.0 \% \pm 17.5$ versus $67.5 \% \pm 31.7, p=0.04$ and $98.6 \% \pm 5.3$ versus $65.8 \% \pm 29.4, p=0.0004$ for the stromal and epithelial compartments, respectively in the superficial layer and $92.9 \% \pm 15.4$ versus $77.5 \% \pm 24.2, p=0.06$ and $100.0 \% \pm 0.0$ versus $88.3 \% \pm 21.3, p=0.03$ for the stromal and epithelial compartments, respectively, in the basal layer) (Figure 1).

The percentage of PR labelled cells in the UPA group was significantly increased in the epithelial cells of both layers as compared to the No-UPA secretory phase $(100.0 \% \pm 0.0$ versus $37.1 \% \pm 38.8, p<$ 0.0001 and $100.0 \% \pm 0.0$ versus $73.3 \% \pm 22.3, p<0.0001$ for the superficial and basal layers, respectively) (Figure 1). This progesterone-antagonist pattern was not observed in the stromal compartment of either layer.

ER and PR expressions in the UPA and post-UPA groups were comparable to the control No-UPA proliferative phase group in both cellular populations of both layers (Figures 1 and A.1).

There was no layer-specific regulation of ER and PR under UPA (Figure A.1).

\section{UPA treatment has no impact on cell proliferation in the basal layer}


223 In the superficial layer in the UPA group, the percentage of Ki67 marked epithelial cells was 224 significantly increased in comparison to the No-UPA secretory phase group and significantly 225 decreased as compared to the No-UPA proliferative phase group $(1.5 \pm 0.5$ versus $1.2 \pm 0.6, p=0.03$ 226 and $1.5 \pm 0.5$ versus $2.1 \pm 0.9, p=0.047$, respectively). In the stroma, Ki67 staining was decreased in 227 comparison to the No-UPA proliferative phase $(1.1 \pm 0.4$ versus $1.8 \pm 0.8, p=0.02)$ (Figure 2$)$.

228 In contrast, in the basal layer, Ki67 staining in the study groups remained unchanged in both cellular 229 compartments.

230 Ki67 staining score in the epithelial cells in the No-UPA proliferative phase and UPA groups was lower 231 in the basal layer as compared to the superficial layer $(2.1 \pm 0.9$ versus $1.4 \pm 0.6, p=0.0204$ and $1.5 \pm$ 2320.5 versus $1.1 \pm 0.3, p=0.0329$ for the No-UPA proliferative phase and UPA groups, respectively) 233 (Figure 3).

UPA has a mixed agonist and antagonist effect on angiogenesis marker in both endometrial 236 layers

237 We observed a layer-specific pattern of progesterone-regulated VEGFR2 expression. In the glandular 238 compartment VEGFR2 was down regulated in the No-UPA secretory phase group as compared to the 239 No-UPA proliferative phase group in the superficial layer $(61.5 \% \pm 50.6$ versus $95.0 \% \pm 18.7, p=0.03)$, 240 but this pattern was not observed in the basal layer. In contrast, VEGFR2 was regulated in the stromal 241 compartment of the basal layer but not in the superficial layer $(27.9 \% \pm 36.0$ versus $4.6 \% \pm 11.3, p=$ 2420.047 for the No-UPA proliferative and secretory phases, respectively, in the stromal compartment of 243 the basal layer) (Figure 2).

244 In the UPA group the regulation of VEGFR2 expression was compartment- and layer-specific. In the 245 superficial layer there was a trend to a proliferative phase-like profile in the glandular epithelium, while 246 in the stromal compartment the trend was towards a secretory phase-like profile, although these 247 results did not reach significance. In the post-UPA proliferative phase group VEGFR2 immunostaining 248 was similar to that observed in the No-UPA proliferative control group in both layers of the endometrium with the exception of the basal layer stromal compartment (Figure 2). 
252 IL-15 expression was not statistically differentially expressed in the No-UPA proliferative and secretory 253 phases in either compartment or layer, although a trend to a decreased expression in the No-UPA 254 secretory phase was observed (Figure 4, Figure A.2). IDO expression was down regulated by 255 progesterone in the glandular epithelium of both layers (Figure 4, Figure A.2). UPA administration 256 resulted in a proliferative phase-like expression profile of IL-15 and IDO in both layers (Figure 4, 257 Figure A.2). In the post-UPA proliferative phase group their expression was similar to the No-UPA 258 control group in all analysed compartments.

259 CCL2 expression profile was similar in both endometrial layers, showing an increased staining in the 260 stromal compartment during the No-UPA secretory phase. In the UPA and post-UPA proliferative 261 phase groups, a proliferative phase-like CCL2 expression pattern was observed in both endometrial 262 layers (Figure 4, Figure A.2). 


\section{DISCUSSION}

264 Our results show that under UPA, ER and PR expression mirrors the proliferative phase in both layers,

265 although with a decrease in cell proliferation. In fact, in the UPA group the ER immunostaining was 266 generally increased as compared to the No-UPA secretory phase, except for the stromal compartment 267 of the basal layer. The percentage of PR labelled cells in the UPA group was significantly increased in 268 the epithelial cells of both layers as compared to the No-UPA secretory phase.

269 IL-15, IDO and CCL2 expressions mirror the proliferative phase, as a proliferative phase-like 270 expression profile of IL-15, IDO and CCL2 was observed in both layers suggesting a progesterone271 antagonist effect of UPA. In contrast VEGFR2 staining suggests a trend to a mixed agonist-antagonist 272 effect, since an intermediary aspect was observed.

273 No significant difference is observed in the post-UPA proliferative phase group as compared to the 274 proliferative phase control group in both layers of the endometrium.

275 This is the first report evaluating the effect of UPA on both layers of the human endometrium. In 276 addition, samples obtained after treatment discontinuation were also evaluated.

277 The long-term impact of SPRM administration on the endometrium is debatable, as morphologically 278 reversible benign alterations - PAEC (Mutter et al., 2008; Williams et al., 2012) - are observed in 11$27926 \%$ of patients treated by UPA, based on endometrial biopsy evaluation (Donnez et al., 2012). In our 280 study we observed PAECs in $14 \%$ of patients treated with UPA. The significance and impact of 281 PAECs on endometrial functions is still incompletely understood since they are also observed in 282 approximately $10 \%$ of women with myomas before any treatment with UPA (Williams et al., 2012). 283 Long-term daily administration of UPA results in blunted progesterone levels, while oestradiol levels 284 are constantly in the early follicular phase range (Chabbert-Buffet et al., 2007), which has raised the 285 question of a potential proliferative effect.

286 Endometrial proliferation (Ki67) and maturation markers (ER, PR, AR, HAND2, FOXO1, HOXA 10, 287 PTEN) have recently been described in endometrial biopsies of women under UPA treatment 288 (Whitaker et al., 2017). Of note, although the short-term effects of mifepristone have been widely 289 studied (for example, in the review by Danielsson et al (Danielsson et al., 2003)), its long-term and 290 post-treatment effects are likewise imperfectly understood, while continuous administration of 
291 asoprisnil, another SPRM, results in an original pattern of expression of endometrial maturation 292 markers (Wilkens et al., 2013).

293 In the previous report of UPA effects in the superficial layer (Whitaker et al., 2017) the authors 294 reported that ER expression mirrored the proliferative phase in stromal and epithelial cells. In the 295 present study, a similar impact of UPA on ER expression profile was observed suggesting an antiprogestin effect of UPA. No effect on ER expression profile was found in the post-UPA proliferative 297 group as compared to the control proliferative group in either endometrial layer, which suggests that 298 UPA impact on ER expression does not persist after treatment discontinuation.

299 Dose- and molecule-specific SPRM effects on PR expression have been described previously 300 (Danielsson et al., 2003; Wilkens et al., 2013). Under UPA, Whitaker et al. (Whitaker et al., 2017) 301 reported that PR expression does not phenocopy either the secretory or proliferative endometrium 302 with a compartment-specific profile in the superficial layer, however in the glandular epithelium PR 303 expression was modified towards a proliferative phase profile. In the present study, under UPA PR 304 expression is proliferative phase-like in both layers. No specific effect was seen after treatment 305 discontinuation. This suggests that UPA has a reversible anti-progestin effect on PR expression.

306 Our results on the impact of UPA on cell proliferation are different from those of Whitaker (Whitaker et 307 al., 2017). In the superficial layer these authors reported a decrease in Ki67 expression under UPA as 308 compared to the proliferative phase in stromal cells, while it was unchanged in the glandular 309 epithelium. In the present study, Ki67 was down regulated compared to the proliferative phase in 310 stromal cells as well, while in the glandular epithelium it was distinct from both the proliferative and 311 secretory phases, suggesting a mixed progesterone agonist-antagonist effect. Altogether, these 312 results suggest an anti-proliferative effect of UPA in the stromal compartment and a specific 313 intermediate effect in the glandular epithelium of the superficial layer of the human endometrium. 314 Importantly, non-specific regulation of Ki67 expression was observed in the basal layer during UPA 315 treatment or after discontinuation, suggesting the absence of any long-term effect of UPA on cell 316 proliferation.

317 The discrepancies between our results and those of Whitaker and colleagues may be due to clinical 318 differences such as a distinct timing in the secretory phase of control samples. In addition, our assessment of Ki67 staining was not automated. However, its evaluation was reproducible and 
320 performed blinded. VEGFR2 is a progesterone-regulated marker. While in the superficial layer

321 VEGFR2 expression was down regulated in the glandular epithelium during the secretory phase,

322 which is consistent with a previous report in the literature (Lai et al., 2015), in the basal layer a distinct 323 and specific pattern of VEGFR2 was observed. VEGFR2 expression was unchanged in the glandular 324 epithelium and down regulated in the stromal cells in the secretory phase.

325 Under UPA there was a trend to a proliferative phase-like profile in the glandular epithelium in the 326 superficial layer. In the stromal compartment the course was towards a secretory phase-like profile in 327 both layers. In the post-UPA proliferative phase group VEGFR2 expression was broadly similar to that 328 observed in the proliferative control group. This is the first report on VEGFR2 staining under UPA. 329 Clinically, UPA treatment results in the rapid control of abnormal uterine bleeding and amenorrhea is 330 observed in $91 \%$ of patients (Donnez et al., 2012). The mechanism behind this effect is still 331 incompletely understood. UPA impact on angiogenesis has been assessed by Ravet and team (Ravet 332 et al., 2008). These authors reported a UPA effect similar to the progesterone action on vascular 333 maturation and proliferation, that is, integrity of the collagen-rich fibrillar network and no change in the 334 relative vascular area or localisation and level of VEGF-A expression.

335 IDO plays a major role in tryptophan degradation (Kudo et al., 2001; Munn et al., 1999), an important 336 pathway in regulatory $\mathrm{T}$ lymphocyte generation and immunosuppression. IDO expression was down 337 regulated in the secretory phase in both endometrial layers as reported previously in the superficial 338 layer (Sedlmayr et al., 2002).

339 IL-15, which regulates proliferation and activation of immune cells, showed a trend to a decreased 340 expression in the secretory phase, while CCL2, which stimulates immune cell migration, displayed a 341 trend to an increased expression in the stromal compartment in the secretory phase. There was no 342 layer-specific pattern of expression. In the literature these markers have been evaluated in 343 miscellaneous situations. In women with either uterine leiomyomas or cervix cancer, IL-15 was 344 detected in the proliferative phase, primarily in the glandular epithelium (Kitaya et al., 2000). Its 345 production increases in stromal cells in the vicinity of spiral arteries during the secretory phase (Kitaya 346 et al., 2000). In healthy women IL-15 mRNA expression was increased in total endometrial samples 347 during the secretory phase (Wilkens et al., 2013). CCL2 expression was increased from the early 348 proliferative phase in endometrial biopsies from unselected women (Jones et al., 1997). These two 349 markers are specifically implicated in endometrial maturation, while ER and PR participate in 
350 endometrial regeneration as well. The differences between our results and the literature regarding the 351 superficial layer might be explained by the fact that in our study endometrial samples were obtained 352 from hysterectomies of selected patients with symptomatic myomas, while different physiological and 353 pathological conditions were included in other studies. It is known that uterine myomas can have a 354 specific effect on expression of endometrial molecular markers (Ikhena and Bulun, 2018; Rackow and 355 Taylor, 2010).

356 Asoprisnil and UPA administration have been reported to result in the reduction of IL15 mRNA 357 (Whitaker et al., 2017; Wilkens et al., 2013). No data is available on the impact of SPRMs on IDO or 358 CCL2 expression. In the present study, a proliferative phase-like effect of UPA on IL-15, IDO and 359 CCL2 expression was found. In the post-UPA proliferative phase group a proliferative phase-like 360 expression profile of these markers suggests a limited impact of UPA on the immunomodulatory 361 processes of endometrial maturation. This is in accordance with data available on emergency 362 contraception with UPA, showing that this molecule does not interfere with embryo implantation 363 (Berger et al., 2015; Gemzell-Danielsson et al., 2014). A series of post-UPA treatment pregnancies 364 has been described in women treated for myomas (Luyckx et al., 2014) and a case report of 365 pregnancy during UPA treatment has recently been published (Hrgovic et al., 2018). UPA may 366 therefore be administered to women willing to conceive in the short term without any consequences 367 for further implantation. .

368 The major strength of our study is the large number of patients from a homogeneous population of 369 women with symptomatic myomas included in the analysis. The analysis of hysterectomy samples 370 permitted the evaluation of both endometrial layers. The immunostaining was assessed by a blinded 371 expert.

372 The limitations of this study include its retrospective design and the absence of hormonal assessment 373 of the menstrual cycle phase. Control sample numbers were limited, as symptomatic myomas require 374 hormonal treatment. The post-UPA group was composed of women in proliferative phase, because 375 the majority of patients without hormonal treatment are operated on in the first phase of the menstrual 376 cycle. Since all included patients were experiencing severe myoma-related symptoms, our data 377 cannot be extrapolated to other clinical situations. Quantification of markers' expression was semiquantitative since paraffin-embedded samples did not allow Western Blot analysis. 
380 CONCLUSION

381 A three-month UPA course exerts a specific, compartment- and layer-dependent effect on the human 382 endometrium. Although in the superficial layer the effect of UPA is mostly PR antagonist-like, our 383 observations regarding the basal layer during treatment and after its discontinuation suggest the 384 absence of a long-term effect of this molecule on endometrial proliferation and maturation. 
387 Table A.1. Primary antibodies used in the study

\begin{tabular}{|c|c|c|c|c|c|c|c|c|}
\hline Protein & $\begin{array}{l}\text { Antibody } \\
\text { reference }\end{array}$ & Species & Pre-treatment & Blocking & Dilution & $\begin{array}{l}\text { Incubation } \\
\text { time }\end{array}$ & Positive control & Isotype control \\
\hline${ }^{\star} \mathrm{PR} \mathrm{SP} 1^{\mathrm{a}}$ & $790-4296$ & $\begin{array}{l}\text { Monoclonal rabbit } \\
\text { lgG }\end{array}$ & $\mathrm{pH} 8.8$ & & Pre-diluted & $24 h$ & Human breast cancer & \\
\hline${ }^{\star} \mathrm{ER} 1 \mathrm{E} 2^{\mathrm{a}}$ & $790-4325$ & $\begin{array}{l}\text { Monoclonal rabbit } \\
\lg \text { lgG }\end{array}$ & $\mathrm{pH} 8.8$ & & Pre-diluted & $24 h$ & Human breast cancer & \\
\hline $\mathrm{IDO}^{\mathrm{b}}$ & ab55305 & $\begin{array}{l}\text { Monoclonal mouse } \\
\text { lgG2b }\end{array}$ & $\begin{array}{l}\text { Citrate buffer pH } 6.0 \\
\text { at } 98^{\circ} \mathrm{C}\end{array}$ & $\begin{array}{l}\text { SNG } 10 \%+\text { BSA } \\
1 \%\end{array}$ & $1 / 150$ & $\begin{array}{l}\text { Overnight, } \\
4^{\circ} \mathrm{C}\end{array}$ & Human spleen & Mouse IgG2b \\
\hline $\mathrm{CCL}^{\mathrm{b}}$ & ab9669 & $\begin{array}{l}\text { Polyclonal rabbit } \\
\text { IgG }\end{array}$ & $\begin{array}{l}\text { Citrate buffer pH } 6.0 \\
\text { at } 98^{\circ} \mathrm{C}\end{array}$ & $\begin{array}{l}\text { SNG } 10 \%+\text { BSA } \\
1 \%\end{array}$ & $1 / 200$ & $\begin{array}{l}\text { Overnight, } \\
4^{\circ} \mathrm{C}\end{array}$ & $\begin{array}{l}\text { Human invasive ductal } \\
\text { breast carcinoma }\end{array}$ & Rabbit IgG \\
\hline $\mathrm{IL}-15^{\mathrm{b}}$ & ab55276 & $\begin{array}{l}\text { Monoclonal mouse } \\
\text { lgG2a }\end{array}$ & $\begin{array}{l}\text { Citrate buffer pH } 6.0 \\
\text { at } 98^{\circ} \mathrm{C}\end{array}$ & $\begin{array}{l}\text { SNG } 10 \%+\text { BSA } \\
1 \%\end{array}$ & $1 / 50$ & $\begin{array}{l}\text { Overnight, } \\
4^{\circ} \mathrm{C}\end{array}$ & $\begin{array}{l}\text { Human invasive ductal } \\
\text { breast carcinoma }\end{array}$ & Mouse lgG2a \\
\hline VEGFR2 ${ }^{\mathrm{C}}$ & sc-6251 & $\begin{array}{l}\text { Monoclonal mouse } \\
\lg \text { G1 }\end{array}$ & $\begin{array}{l}\text { EDTA buffer } \mathrm{pH} 8.0 \\
\text { at } 98^{\circ} \mathrm{C}\end{array}$ & SNG 10\% & $1 / 50$ & $30 \min , \mathrm{RT}$ & Human colon carcinoma & Mouse IgG1 \\
\hline${ }^{\star} \mathrm{Ki} 67 \mathrm{Mib1}^{\mathrm{d}}$ & M7240 & $\begin{array}{l}\text { Monoclonal mouse } \\
\lg \text { IgG }\end{array}$ & $\mathrm{pH} 8.8$ & & $1 / 150$ & $32 h$ & Tonsil & Mouse IgG \\
\hline
\end{tabular}

${ }^{a}$ Ventana Medical Systems, Inc.

Abcam, France

'Santa Cruz Biotechnology, USA

dDAKO

*Automate BenchMark XT, Roche Ventana®, (Ventana Medical Systems, Inc.)

IL-15, interleukin-15; IDO, indoleamin-2,3-dioxygenase; CCL2, C-C motif chemokine ligand-2; VEGFR2, vascular endothelial growth factor-2; SNG, serum normal goat (Clinisciences); BSA, bovine serum albumin (Sigma-Aldrich); EDTA, ethylenediaminetetraacetic acid (Ivitrogen); RT, room temperature 
396 Figure A.1. Oestrogen (ER) and progesterone (PR) receptor expression is layer dependent in 397 the epithelial compartment.

398 The quantification of ER and PR immunostaining expressed as a percentage of marked cells in each

399 endometrial layer. ${ }^{*} p<0.05$. Error bars: mean \pm SD.

400 Under UPA, the percentage of ER stained cells in the stroma was $90.0 \% \pm 17.5$ in the superficial layer

401 versus $92.9 \% \pm 15.4$ in the basal layer $(p=0.7186)$ and in the epithelium $98.6 \% \pm 5.3$ in the superficial 402 versus $100.0 \% \pm 0.0$ in the basal layers $(p=1)$. The percentage of PR stained cells in the stroma was $40396.4 \% \pm 9.3$ in the superficial layer versus $97.9 \% \pm 8.0$ in the basal layer $(p=1)$ and in the epithelium $404100.0 \% \pm 0.0$ in the superficial versus $100.0 \% \pm 0.0$ in the basal layers $(p=1)$.

405 UPA, ulipristal acetate

406 Figure A.2. VEGFR2, IL-15, IDO and CCL2 expression in both endometrial layers.

408 The quantification of IL-15, IDO and CCL2 immunostaining expressed as a percentage of marked cells 409 in each endometrial layer. ${ }^{*} p<0.05,{ }^{* *} p<0.005$. Error bars: mean \pm SD.

410 VEGFR2, vascular endothelial growth factor-receptor 2; IL-15, interleukin-15; IDO, indoleamin-2,3411 dioxygenase; CCL2, C-C motif chemokine ligand-2 


\section{VITAE}

414 Nathalie Chabbert-Buffet, MDPhD, is a reproductive medicine and endocrinology specialist, working at

415 a university hospital - Obstetrics Gynaecology and Reproductive Medicine department, Assistance

416 Publique Hôpitaux de Paris, Sorbonne University. Research topics are focused more specifically on

417 endometrial physiology and diseases, and endometrial impact of hormone treatments.

418

\section{KEY MESSAGE}

420 Ulipristal acetate (UPA) effects on proliferation and maturation markers in both endometrial layers

421 during treatment and after discontinuation suggest the absence of long-term effect. 


\section{REFERENCES}

Ban, Y., Chang, Y., Dong, B., Kong, B., and Qu, X., 2013. Indoleamine 2,3-dioxygenase levels at the normal and recurrent spontaneous abortion fetal-maternal interface. J. Int. Med. Res. 41, 1135-1149.

Berger, C., Boggavarapu, N.R., Menezes, J., Lalitkumar, P.G.L., and Gemzell-Danielsson, K., 2015. Effects of ulipristal acetate on human embryo attachment and endometrial cell gene expression in an in vitro co-culture system. Hum. Reprod. 30, 800-811.

Bouchard, P., Marraoui, J., Massai, M.R., Medalie, D.A., De Ziegler, D., Perrot-Applanat, M., Frydman, R., and Bergeron, C., 1991. Immunocytochemical localization of oestradiol and progesterone receptors in human endometrium: a tool to assess endometrial maturation. Baillieres Clin Obstet Gynaecol. 5, 107-115.

Bouchard, P., Chabbert-Buffet, N., and Fauser, B.C.J.M., 2011. Selective progesterone receptor modulators in reproductive medicine: pharmacology, clinical efficacy and safety. Fertil. Steril. 96, 1175-1189.

Caballero-Campo, P., Domínguez, F., Coloma, J., Meseguer, M., Remohí, J., Pellicer, A., and Simón, C. 2002. Hormonal and embryonic regulation of chemokines IL-8, MCP-1 and RANTES in the human endometrium during the window of implantation. Mol. Hum. Reprod. 8, 375-384.

Chabbert-Buffet, N., Pintiaux-Kairis, A., Bouchard, P., and VA2914 Study Group, 2007. Effects of the progesterone receptor modulator VA2914 in a continuous low dose on the hypothalamic-pituitaryovarian axis and endometrium in normal women: a prospective, randomized, placebo-controlled trial. J. Clin. Endocrinol. Metab. 92, 3582-3589.

Croxatto, D., Vacca, P., Canegallo, F., Conte, R., Venturini, P.L., Moretta, L., and Mingari, M.C., 2014. Stromal cells from human decidua exert a strong inhibitory effect on NK cell function and dendritic cell differentiation. PLoS ONE. 9, e89006.

Danielsson, K.G., Marions, L., and Bygdeman, M., 2003. Effects of mifepristone on endometrial receptivity. Steroids. 68, 1069-1075.

Dimitriadis, E., White, C.A., Jones, R.L., and Salamonsen, L.A., 2005. Cytokines, chemokines and growth factors in endometrium related to implantation. Hum. Reprod. Update. 11, 613-630.

Donnez, J., and Dolmans, M.-M., 2016. Uterine fibroid management: from the present to the future. Hum. Reprod. Update. 22, 665-686.

Donnez, J., Tatarchuk, T.F., Bouchard, P., Puscasiu, L., Zakharenko, N.F., Ivanova, T., Ugocsai, G., Mara, M., Jilla, M.P., Bestel, E., et al., 2012. Ulipristal acetate versus placebo for fibroid treatment before surgery. N. Engl. J. Med. 366, 409-420.

Gellersen, B., Brosens, I.A., and Brosens, J.J., 2007. Decidualization of the human endometrium: mechanisms, functions, and clinical perspectives. Semin. Reprod. Med. 25, 445-453.

Gemzell-Danielsson, K., Berger, C., and Lalitkumar, P.G., 2014. Mechanisms of action of oral emergency contraception. Gynecol. Endocrinol. 30, 685-687.

Hrgovic, Z., Habek, D., Cerkez Habek, J., Hrgovic, I., Jerkovic Gulin, S., and Gulin, D., 2018. Spontaneous pregnancy during ulipristal acetate treatment of giant uterine leiomyoma. J Clin Pharm Ther. 43, 121-123.

Ikhena, D.E., and Bulun, S.E., 2018. Literature Review on the Role of Uterine Fibroids in Endometrial Function. Reprod. Sci. 25, 635-643.

Jones, R.K., Searle, R.F., Stewart, J.A., Turner, S., and Bulmer, J.N., 1998. Apoptosis, bcl-2 expression, and proliferative activity in human endometrial stroma and endometrial granulated lymphocytes. Biol. Reprod. 58, 995-1002. 
Jones, R.L., Kelly, R.W., and Critchley, H.O., 1997. Chemokine and cyclooxygenase-2 expression in human endometrium coincides with leukocyte accumulation. Hum. Reprod. 12, 1300-1306.

469 Kayisli, U.A., Mahutte, N.G., and Arici, A., 2002. Uterine chemokines in reproductive physiology and 470 pathology. Am. J. Reprod. Immunol. 47, 213-221.

Kitaya, K., Yasuda, J., Yagi, I., Tada, Y., Fushiki, S., and Honjo, H., 2000. IL-15 expression at human endometrium and decidua. Biol. Reprod. 63, 683-687.

Kudo, Y., Boyd, C.A., Sargent, I.L., and Redman, C.W., 2001. Tryptophan degradation by human placental indoleamine 2,3-dioxygenase regulates lymphocyte proliferation. J. Physiol. (Lond.). 535, 207-215.

Kudo, Y., Hara, T., Katsuki, T., Toyofuku, A., Katsura, Y., Takikawa, O., Fujii, T., and Ohama, K., 2004. Mechanisms regulating the expression of indoleamine 2,3-dioxygenase during decidualization of human endometrium. Hum. Reprod. Oxf. Engl. 19, 1222-1230.

Lai, T.-H., Vlahos, N., Shih, I.-M., and Zhao, Y., 2015. Expression Patterns of VEGF and Flk-1 in Human Endometrium during the Menstrual Cycle. J. Reprod. Infertil. 16, 3-9.

Lash, G.E., Bulmer, J.N., Li, T.C., Innes, B.A., Mariee, N., Patel, G., Sanderson, J., Quenby, S., and Laird, S.M., 2016. Standardisation of uterine natural killer (UNK) cell measurements in the endometrium of women with recurrent reproductive failure. J. Reprod. Immunol. 116, 50-59.

Luyckx, M., Squifflet, J.-L., Jadoul, P., Votino, R., Dolmans, M.-M., and Donnez, J., 2014. First series of 18 pregnancies after ulipristal acetate treatment for uterine fibroids. Fertil. Steril. 102, 1404-1409.

Munn, D.H., Shafizadeh, E., Attwood, J.T., Bondarev, I., Pashine, A., and Mellor, A.L., 1999. Inhibition of T cell proliferation by macrophage tryptophan catabolism. J. Exp. Med. 189, 1363-1372.

Mutter, G.L., Bergeron, C., Deligdisch, L., Ferenczy, A., Glant, M., Merino, M., Williams, A.R.W., and Blithe, D.L., 2008. The spectrum of endometrial pathology induced by progesterone receptor modulators. Mod. Pathol. 21, 591-598.

Noyes, R.W., Hertig, A.T., and Rock, J., 1975. Dating the endometrial biopsy. Am. J. Obstet. Gynecol. 122, 262-263.

Okada, H., Nakajima, T., Sanezumi, M., Ikuta, A., Yasuda, K., and Kanzaki, H., 2000. Progesterone enhances interleukin-15 production in human endometrial stromal cells in vitro. J. Clin. Endocrinol. Metab. 85, 4765-4770.

Perrier D'hauterive, S., Charlet-Renard, C., Goffin, F., Foidart, M., and Geenen, V., 2002. [The implantation window]. J Gynecol Obstet Biol Reprod (Paris). 31, 440-455.

Rackow, B.W., and Taylor, H.S., 2010. Submucosal uterine leiomyomas have a global effect on molecular determinants of endometrial receptivity. Fertil. Steril. 93, 2027-2034.

Ravet, S., Munaut, C., Blacher, S., Brichant, G., Labied, S., Beliard, A., Chabbert-Buffet, N., Bouchard, 501 P., Foidart, J.-M., and Pintiaux, A., 2008. Persistence of an intact endometrial matrix and vessels 502 structure in women exposed to VA-2914, a selective progesterone receptor modulator. J. Clin. 503 Endocrinol. Metab. 93, 4525-4531.

Sedlmayr, P., Blaschitz, A., Wintersteiger, R., Semlitsch, M., Hammer, A., MacKenzie, C.R., Walcher, W., Reich, O., Takikawa, O., and Dohr, G., 2002. Localization of indoleamine 2,3-dioxygenase in human female reproductive organs and the placenta. Mol. Hum. Reprod. 8, 385-391. 
509 Whitaker, L.H.R., Murray, A.A., Matthews, R., Shaw, G., Williams, A.R.W., Saunders, P.T.K., and 510 Critchley, H.O.D., 2017. Selective progesterone receptor modulator (SPRM) ulipristal acetate (UPA) 511 and its effects on the human endometrium. Hum. Reprod. 32, 531-543.

512 Wilkens, J., Male, V., Ghazal, P., Forster, T., Gibson, D.A., Williams, A.R.W., Brito-Mutunayagam, S.L., 513 Craigon, M., Lourenco, P., Cameron, I.T., et al., 2013. Uterine NK cells regulate endometrial bleeding 514 in women and are suppressed by the progesterone receptor modulator asoprisnil. J. Immunol. 191, 515 2226-2235.

516 Williams, A.R.W., Bergeron, C., Barlow, D.H., and Ferenczy, A., 2012. Endometrial morphology after 517 treatment of uterine fibroids with the selective progesterone receptor modulator, ulipristal acetate. Int. 518 J. Gynecol. Pathol. 31, 556-569. 
Figure 1. Ulipristal acetate (UPA) treatment modifies the expression of the oestrogen receptor (ER) and progesterone receptor (PR) in both layers of the endometrium.

Representative images showing immuno-localisation of ER and PR in the superficial (A-D, I-L) and basal $(E-H, M-P)$ layers of the endometrium of women with symptomatic fibroids during No-UPA proliferative and secretory phases, at the end of the cycle of 3 months of UPA treatment and after discontinuation. (-) Negative control: human breast cancer without expression of PR and ER, respectively. Magnification $\times 200$ (scale bar $=100 \mu \mathrm{m}$ ).

The quantification of $E R(Q$ and $S)$ and $P R(R$ and $T)$ immunostaining expressed as a percentage of marked cells in each endometrial layer. ${ }^{*} p<0.05,{ }^{* *} p<0.005,{ }^{* * *} p<0.001$. Error bars: mean \pm SD. $\mathrm{SC}$, stromal cells; GE, glandular epithelium.

Figure 2. Ulipristal acetate (UPA) treatment has no impact on Ki67 expression in the basal layer and has a mixed agonist-antagonist effect on vascular endothelial growth factor-receptor 2 (VEGFR2).

Representative images showing immuno-localisation of Ki67 and VEGFR2 in the superficial (A-D, I-L) and basal $(E-H, M-P)$ layers of the endometrium of women with symptomatic fibroids during No-UPA proliferative and secretory phases, at the end of the cycle of 3 months of UPA treatment and after discontinuation. (-) Negative control: Ki67 - non-specific antibody isotype control, VEGFR2 - human endometrium + non-specific antibody isotype control. Magnification x200 (scale bar $=100 \mu \mathrm{m})$. The quantification of Ki67 ( $Q$ and S) and VEGFR2 (R and T) immunostaining expressed as a percentage of marked cells in each endometrial layer. ${ }^{*} p<0.05,{ }^{* *} p<0.005$. Error bars: mean $\pm S D$.

$\mathrm{SC}$, stromal cells; GE, glandular epithelium.

\section{Figure 3. Ki67 expression is layer dependent.}

The quantification of Ki67 immunostaining expressed as a percentage of marked cells in each endometrial layer. ${ }^{*} p<0.05,{ }^{* *} p<0.005$. Error bars: mean \pm SD.

UPA, ulipristal acetate

Figure 4. Ulipristal acetate (UPA) treatment has an anti-progesterone effect on immunological markers.

Representative images showing immuno-localisation of IL-15, IDO and CCL2 in the superficial (A-D, I$L$ and $Q-T)$ and basal (E-H, M-P and U-X) layers of the endometrium of women with symptomatic fibroids in the No-UPA proliferative phase, the secretory phase, the UPA and the post-UPA groups. (-) Negative control: human endometrium + non-specific antibody isotype control. Magnification x200 (scale bar $=100 \mu \mathrm{m}$ ).

The quantification of IL-15 (Y and $A B)$, IDO ( $Z$ and $A C)$ and CCL2 (AA and AD) immunostaining expressed as a percentage of marked cells in each endometrial layer. ${ }^{\star} p<0.05,{ }^{* *} p<0.005$. Error bars: mean \pm SD.

SC, stromal cells; GE, glandular epithelium; IL-15, interleukin-15; IDO, indoleamin-2,3-dioxygenase; CCL2, C-C motif chemokine ligand-2. 
$564 \quad$ Figure 1.
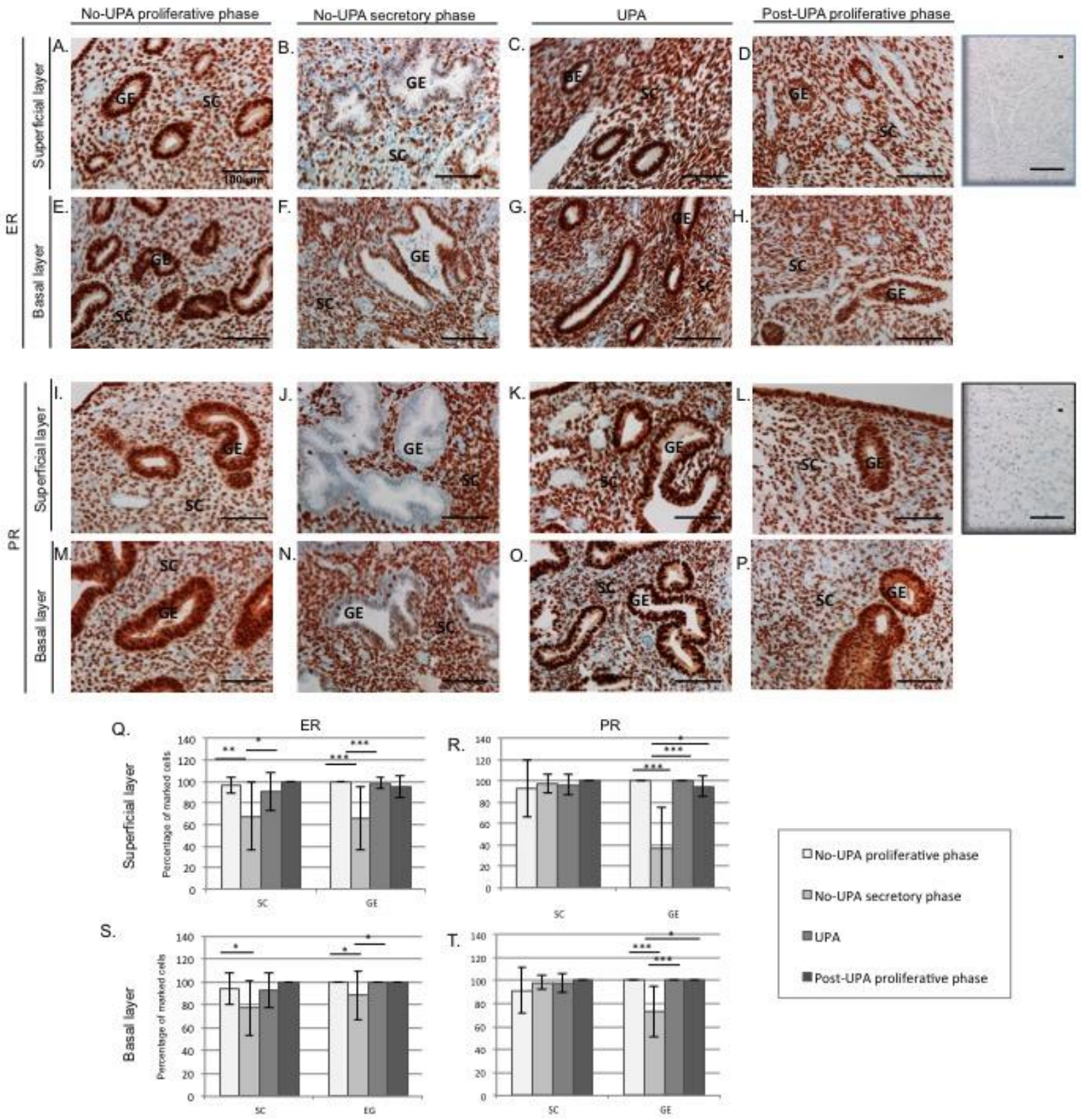

565

566

567 
$568 \quad$ Figure 2.
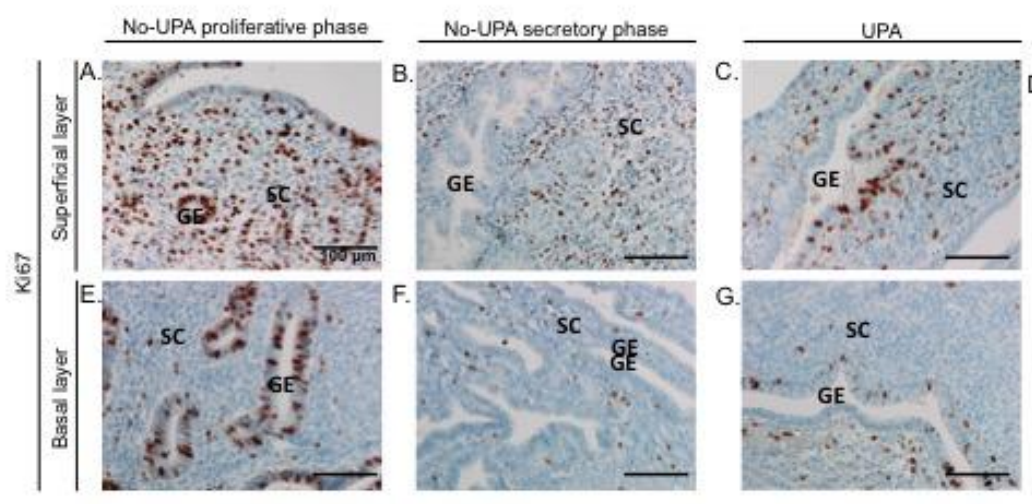

Post-UPA proliferative phase
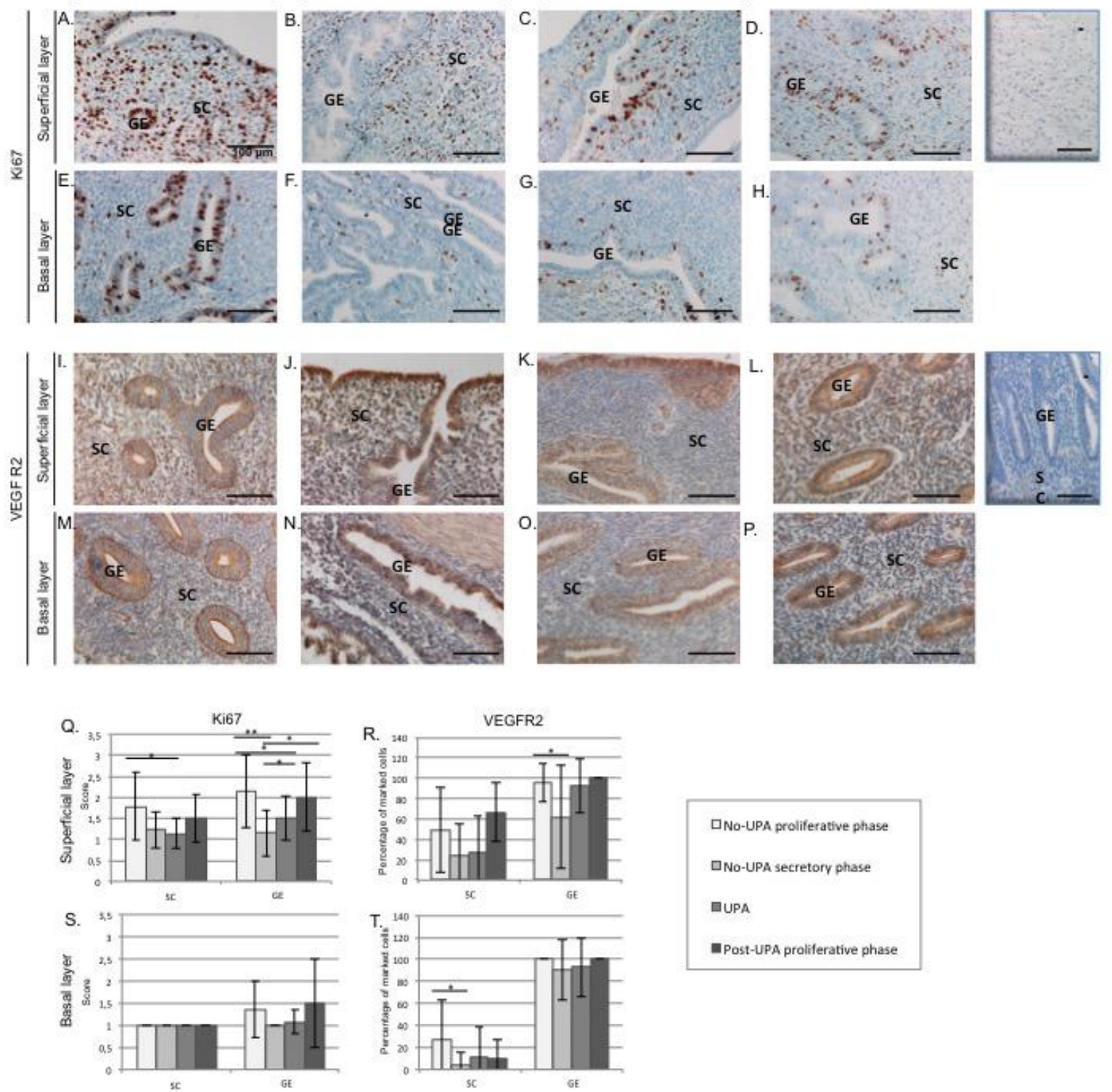
$574 \quad$ Figure 3.

Stromal cells

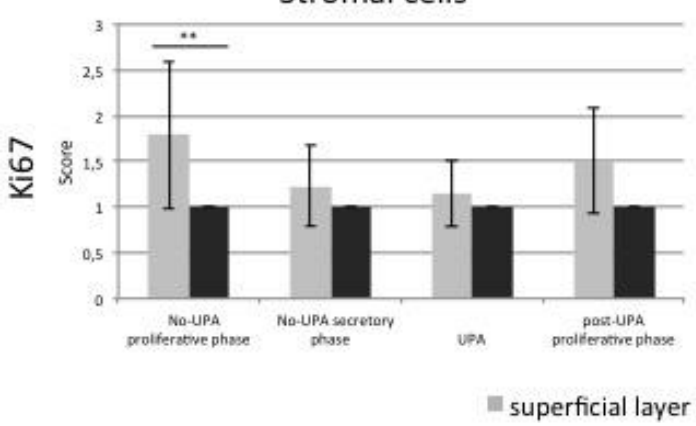

Epithelial cells

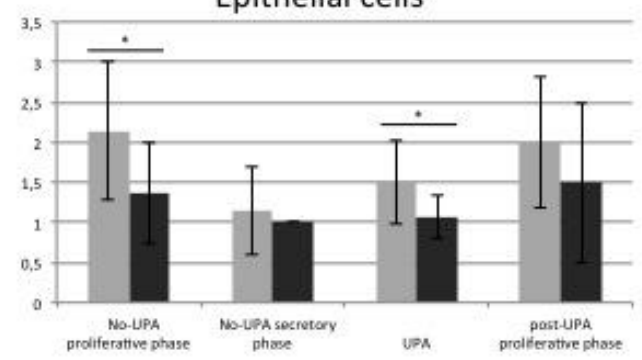

- basal layer 
$579 \quad$ Figure 4.
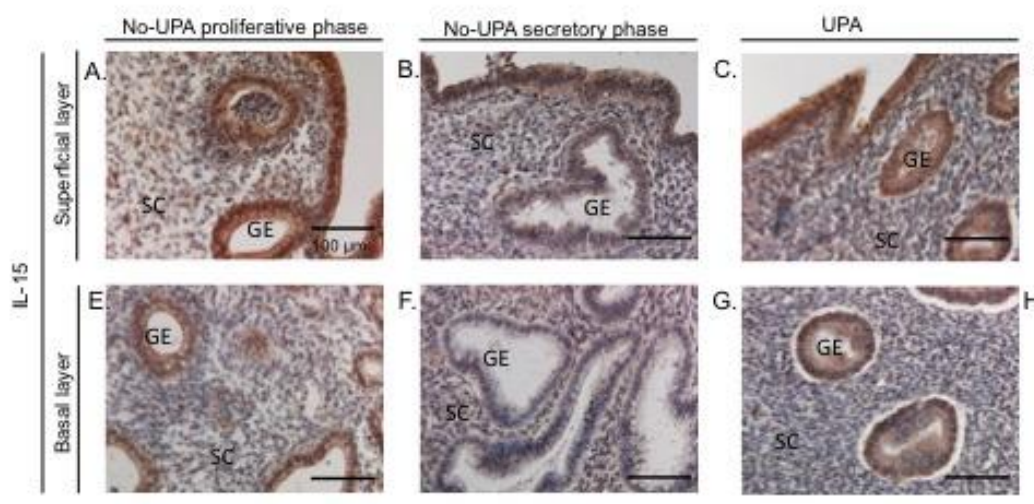

Post-UPA proliferative phase
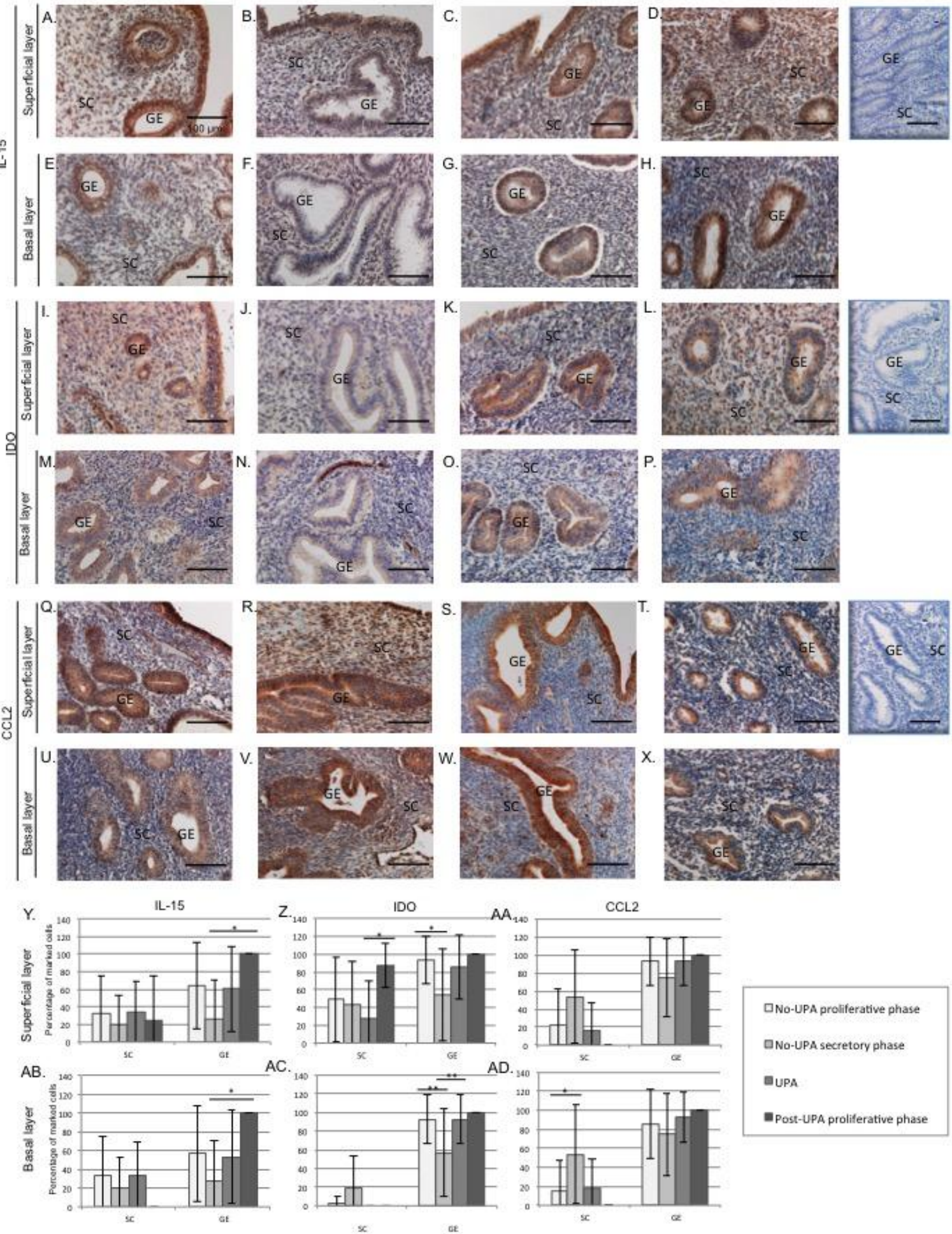
583 Figure A.1.

Stromal cells
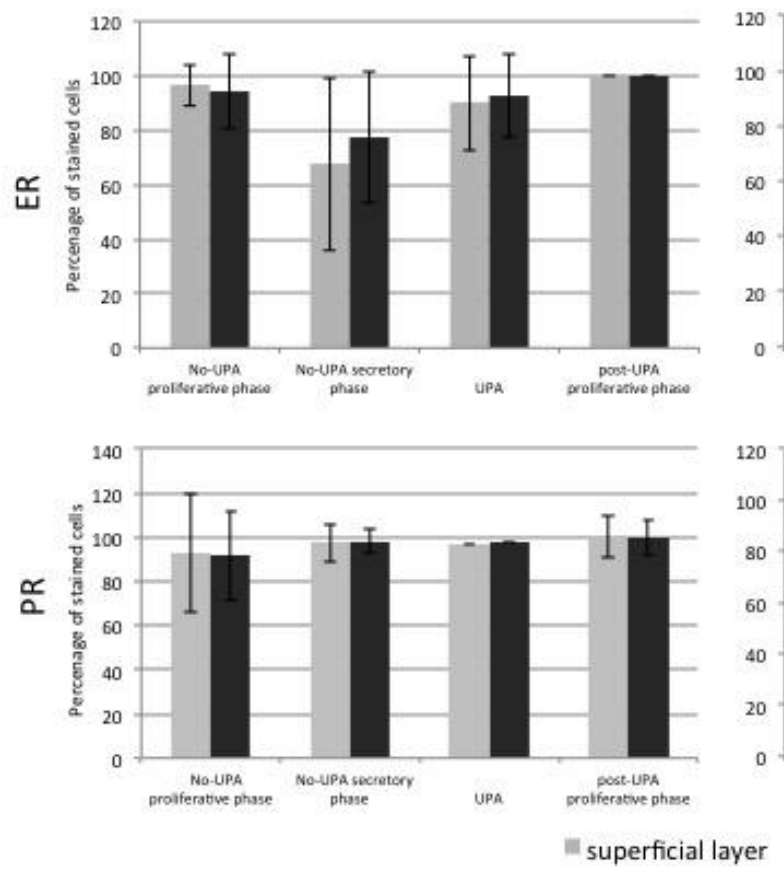

Epithelial cells
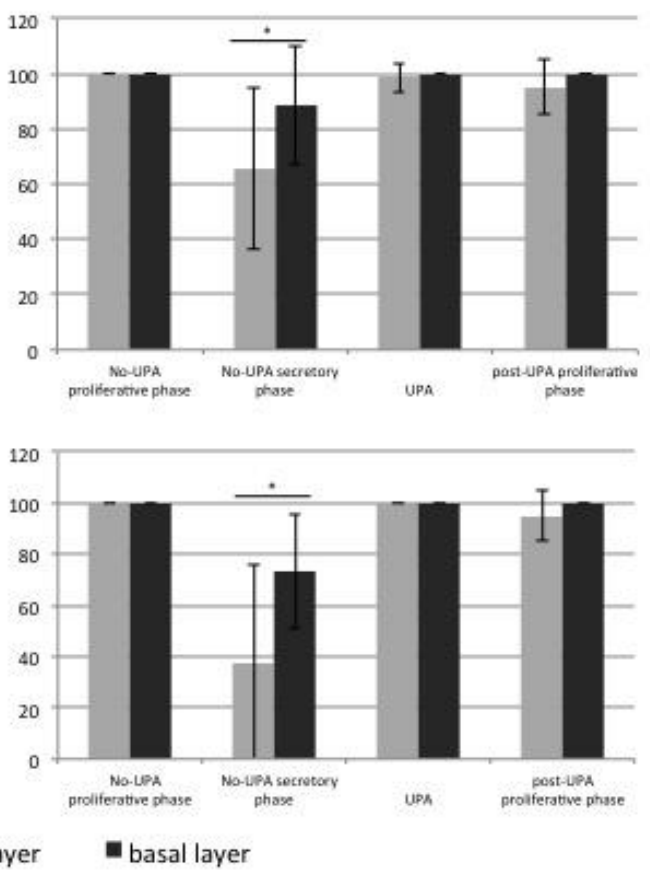

584

585 
588 Figure A.2.
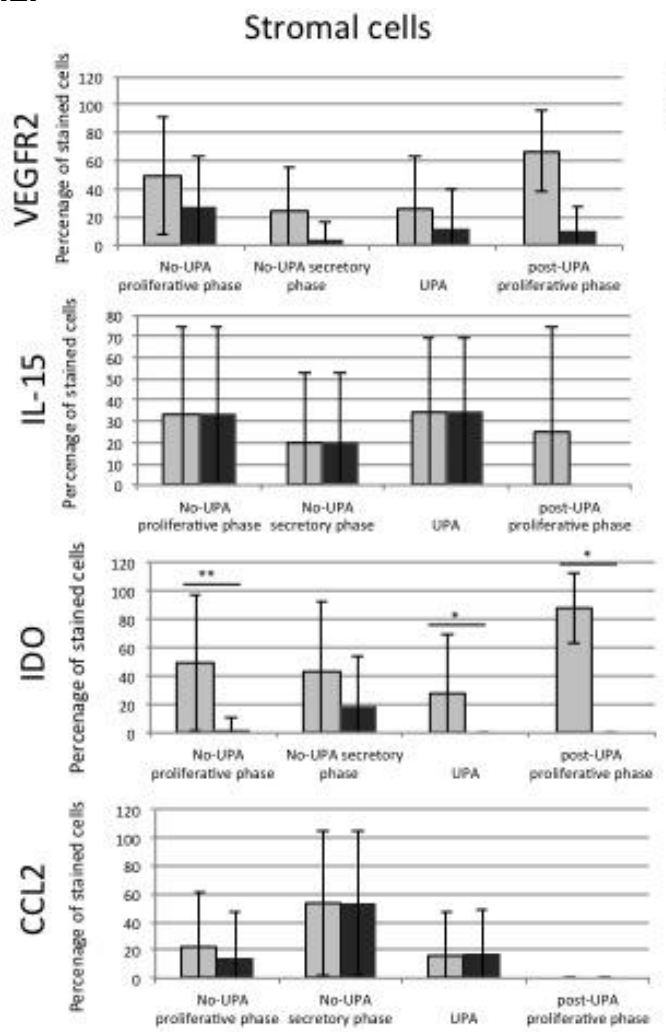
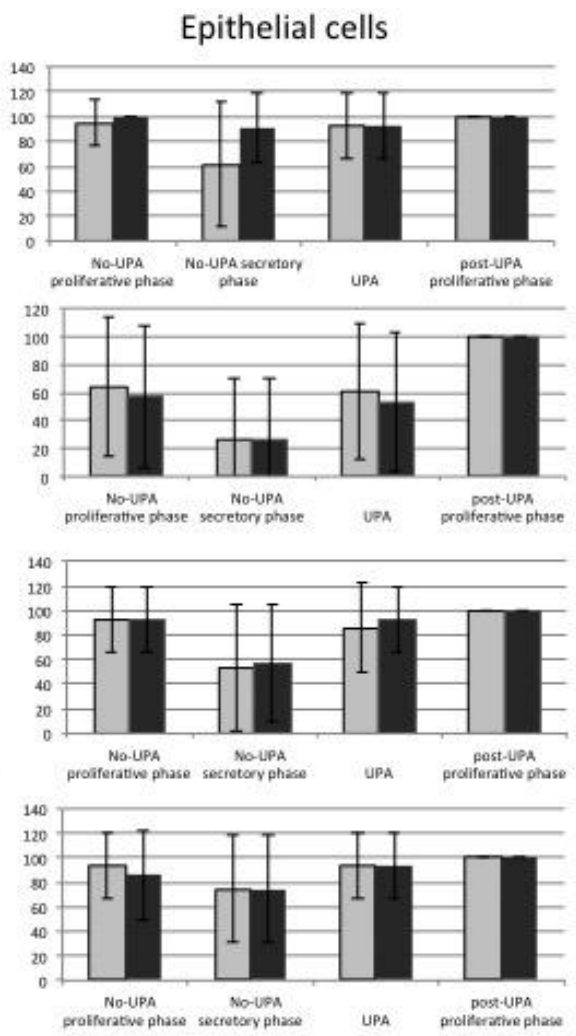
591 Author photo

592

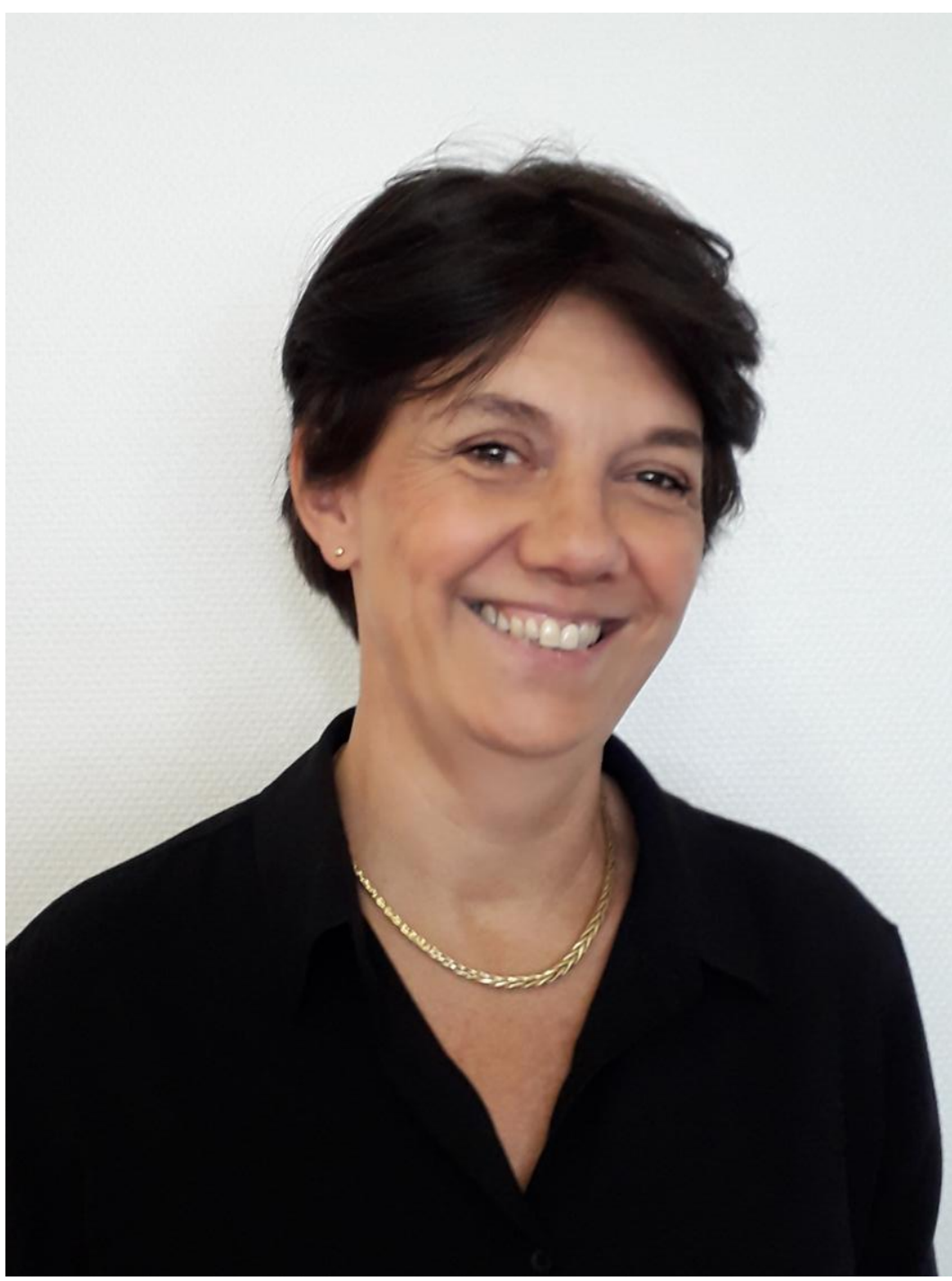

